\author{
Mirjana P. Mirchevska (North Macedonia) \\ Institute of Ethnology and Anthropology \\ Faculty of Natural Sciences and Mathematics \\ Ss. Cyril \& Methodius - Skopje \\ E-mail: miramir@pmf.ukim.edu.mk
}

\title{
ANTHROPOLOGY O SOCIALISM: AUTO-REFLEXIVE MEMORIES OF THE YUGOSLAV PEOPLE'S ARMY
}

\begin{abstract}
This paper presents a memory on the Yugoslav People's Army (YPA), it is a personal perception of certain phenomena and events that took place during the existence of the Socialistic Yugoslav state, which is absent from the global political scene for almost 30 years. However, it is still a topic of discussions, debates and deliberations concerning the specific way of practicing socialism, that did not resemble any other system of the same period. Yugoslav socialism, analyzed from today's chronological and historical distance, gives rise to conflicting opinions and varying view-points and interpretations. Some think that this system was created to minimize any individuality, continuously forcing unity at different levels, while others find that the very unity stimulated equality and social justice, manifested through care for everyone (providing employment, habitation, health insurance, a number of other privileges such as free education, the so called "child allowance", free holidays for workers etc.). All these were basic elements of Yugoslav socialism, at least up to the beginning of the 9oties of the $20^{\text {th }}$ century.
\end{abstract}

In these circumstances, the Yugoslav people's army played a huge role. Forcing the ideological element of communism, it became an imperative for the majority of people. In fact the whole Yugoslav socialism was a part of an ideology that was directed towards a communist society. The term "ideology" refers above all to the so called totalitarian regimes, closed systems that generate attitudes and explanations about everything, without allowing other opinions, thus trying to imply their own view-points as the only possible and correct ones. Today, if we understand ideologies as symbolical systems, they present a separate type of cultural constructions that offer explanations for concrete, clearly defined value interpretations of different phenomena and global processes.

Keywords: Yugoslavia, socialism, Yugoslav People's Army, soldiers, army, Josip Broz Tito, Communist Party, unity and brotherhood, banquet

If one analyses memories in the context of the culture of remembrance, the results might differ. Some memories can be public, others individual, but they can also be collective. Public memories are those that are selected and promoted, 
presented and imposed through created mechanisms by the current government in accordance to its needs. Thus, they are formed in accordance to the ideas and values that are in the focus of the current political culture, incorporating a number of interests: personal, traditional, and professional. The relation between all these memories is not always harmonious, but complex, full of overlapping, additions and contradictions. ${ }^{1}$ Individual memories are related to the individual, the person that lived though a concrete period, and in a direct or indirect way has participated in the cultural and historical events. Individual memories can be related also to a certain collective from the past, but also to a collective that is created in the current moment, and is connected to the lived past. ${ }^{2}$ This is the way memories are sustained and developed, about a period about which different individuals have different feelings, that form their own remembrance in the context of the present. It is a fact that the relation towards memories is always formed in the context of the present, and reflects the current situation of the individual in the society. This is how society produces two sides: one that has a positive attitude towards recent past, and other that has a negative attitude, mainly depending what were theirs (or their parents and family) positions during this period. There is another category, in which an individual has attained one's own position in the current society, often a high one, and in line with the current government, that according to a informal rule has a critical attitude towards the recent cultural and historical past, regardless of their own (and their family's) position in it. Today they have their own position in the community upon which they base, they form and build one's own opinion influenced by the public attitudes of the current government, on a macro or on a local level (village, city, state). In this way the collective memory is conditioned through selective collective forgetting ${ }^{3}$, or as Ilka Thiessen says - memory is created through a stimulated process of forgetting and recollecting. 4 This takes place partly due to the fact that a part of new generations has a different outlook on the past, and their feelings and interpretations are diverse. They do not take it for granted, but they re-evaluate it, proposing new resolutions regarding certain issues, such as: What if this was solved in this particular way, and not as it was actually done? Usually when posing questions like these the historical context is not taken into account, and a number of events are interpreted from today's historical position.

1 Kuljić T. 2003. Tito u novom srpskom poretku sećanja [Tito in the New Serbian Memory Order], Sociologija XLV (2):98. Beograd.

2 Such are a number of social-network profiles that connect people who support or a fans of the previous system and the ex-state - SFRJ Jugoslavija, Jugoslavija naša domovina, Titova Jugoslavija, Jugoslavija za početnike i ponavljače, SFRJ Jugoslavija- SFRJ Jugoslavija, Jugoslavija i Tito, Priznajem Jugosloven sam, Svi koji bi želeli da se vrati Jugoslavija and others.

3 Мирчевска П.М. 2014. 'Конструирање на сегашноста преку преиспитување на минатото: помеѓу јавниот дискурс и личната перцепција' [Construction of the present through re-examining the past: between the public discourse and the personal perception], in За етнологијата... Безброј прагови сме преминале... За Анета Светиева, 158. Скопје: Институт за етнологија и антропологија, ПМФ.

4 Тисен И. 2010. Чекајќи ја Македонија. Идентитет во свет кој се менува[Waiting for Macedonia: Identity in a Changing World], Скопје: Табахон, 62. 
One compares chronologically and geographically distant events that are not well known, and whose interpretations are not sufficiently clear. Past phenomena, processes and characters that have been treated as wrong and damaging for the community now gain new dimensions and are categorized as positive. While the past system focused upon the lesser sides of those persons and events, now their strong sides are sought, that sometimes leads to confusion or suspicion. One poses the question: What is truth, or where is the truth in all of this? This is the overall situation that describes the past three decades in the Republic of Macedonia (since one year ago officially named the Republic of North Macedonia), although the same could apply to a number of ex-Yugoslav countries. ${ }^{5}$ Immediately after the different republics got their independence, researchers have tried to answer questions that have not been posed before. Although for a long time there was an understanding that the ethnologist should research and write about the past, even in Macedonian ethnology and anthropology during the last years there are articles that cover the present, or at least the not so distant and lived past. The first published text referring to this topic (at least to my knowledge), is the one of Dunja Rightman Augushtin ${ }^{6}$, in which she speaks about the pressing need of ethnological research of socialism. In it she says: "The suggested auto-reflection should show how the system of political power concretely limits scientific perception". I find that the core of this sentence even after three decades has not lost its relevance. This is especially important since it comes from an author that has herself lived the Yugoslav socialism. So had I.

Although in general Yugoslav socialism was similar on the territory of the whole Yugoslav federation, still realistically and practically it was not the same if one lived in Ljubljana or Zagreb, Skopje or Titograd (today Podgorica). It was not the same if one was a descendant of former owners of large portions of land, that were nationalized by the new socialistic and communist government, that could obtain only up to 10 hectares. It was not the same if one was a descendant of parents that came to the city to work or to get educated from the village and remained here forming a family, buying and apartment, or after the Skopje earthquake, obtaining an apartment. It was also not the same if one was a worker's family child or if one's parents were intellectuals, if only one family member was employed or both parents. It was not the same if one was a child of a military personnel or not. All these people had their own development, their own feelings and understandings of the practiced and lived socialism, partly through the lives and the experiences of their parents. Today, all these children from that period are adults (even seniors), persons that live in today's pluralistic and multiple political

5 In this article I use "Yugoslav states" for the states that stemmed from ex-Yugoslavia, instead of "Balkan states" that is used by most researchers when they write about former Yugoslav republics, since I find the latter not suitable. Namely, there are states at the Balkans that had different socialisms (or non-socialisms), such as Albania, Bulgaria, Romania, Greece. However the aforementioned articles do not refer to them, but to the Yugoslav republics. This is why I find that the term "Yugoslav states" is more appropriate and more precise.

6 Rihtman-Auguštin D. 1992. Etnologija socijalizma i poslije [The Ethnology of Socialism and Beyond], Etnološka tribina 15: 84. Zagreb. 
parties society, but they all have different relation towards their own socialistic past. Surely their subjective memory selection is auxiliary to these differences.

This is a part of my feelings and of my current interpretation of socialism, seen through one particular socialistic element: the Yugoslav People's Army YPA. In another article published in the journal of the Bulgarian Academy of Sciences ${ }^{7}$ I've made an attempt to research how religion influences the personal narrative of socialism. In this article I will try, partly and selectively, to explain the relation towards YPA, the way I have felt it during my lived experience with socialistic praxis. Since I have not served the army, and thus have no personal experience of being an insider, it will be only partially auto-reflexive, otherwise presenting information gathered through research.

There were three basic postulates upon which Yugoslav socialism and the Yugoslav state were based: the "character and the deeds" of Josip Broz Tito, the Yugoslav People's Army and the Communist Party of Yugoslavia, later re-named to the Union of Communists of Yugoslavia. The basic connective tissue of all these institutions was the socialistic system and the emphasized "brotherhood and unity" among different "people and ethnic groups" 8 in SFRY. I find that the latter was the strongest element of the state, at all levels, in all institutions and structures. However, the status of few elements of the socialistic state was different in the Yugoslav states that stemmed from the common one. Generally, according to my opinion that could be contested ${ }^{9}$, the opinions of the average Yugoslav then and now (Macedonians, Serbs, Montenegrins, Croatians, Bosnians and Slovenians), but also in the current states (Albanians ${ }^{10}$, Roma, Turks, Vlachs etc.), are relatively positive, more positive than when it comes to the official state governing bodies. This is partly a result of the almost 30-year long period of independence and transition of each particular state, and the individual in its frames. The Republic of Macedonia is one of those states where transition was followed by events that for many people meant closing of factories and redundancy, lack of employment, suspicious privatization, low quality education and health system. All this led to lowering of the living standard, and to general displeasure of the majority. This was the basis to create a fertile ground for comparison of the previous system with the current one. The common person has perceived this through a reflection that the system has created directly for his or her family. Thus, for a number of people the previous Yugoslav socialistic system was better, especially for the worker, who spoke with nostalgia about that period, when everyone lived better. Surely, during these past years new citizens were created that called the previous

7 Мирчевска М. 2006. 'Между вярата, традицията и забавлението (антроположки поглед)' [In Between Faith, Tradition and Forgetting: An Anthropological View], in „Заврьщане“ на религиозността, Academica Balkanica 3: 50-62. София: БАН.

8 In today's terminology (in Macedonian) the term "ethnic groups" ("narodnosti” was firstly changed to "ethnic minorities", while today the term "ethnic communities" is used.

9 No matter how much one tries to be objective, it is a fact that most of the articles related to this topic contain subjectivity and auto-reflexivity of their authors.

10 Today Republic of Kosovo is an independent state, stemming from ex-autonomous region Kosovo and Metohija, which was part of the Socialistic Republic of Serbia. 
system "a regime", "totalitarian", one-party system, and "non-democratic". During the last decade and a half, a lot of literature was published which from a different expert and scientific aspect interprets different socio-cultural elements of socialism: everyday life, popular culture, socialistic economy, collectivization, religion, the unique so called "self-governing socialistic system", according to which, at least theoretically - the workers managed the companies and the factories, all of these as part of the nostalgia related to the good sides of the exsystem. Nostalgia results in magnifying certain characters, especially the one of Josip Broz Tito, and there are even new language coinages related to this type of nostalgia. ${ }^{11}$ Defined as a political mythology that does not have either a state or an institutional support, it appears with many different groups and lacks a concrete center, manifesting itself through different forms. ${ }^{12}$ In relation to the previously said, at the level of the present Yugoslav states, it seems that only the status of the Yugoslav People's Army does not have the same meaning. This is understandable, having in mind the wars that took place at the territory of SFRY, and that, at least at the beginning, were led by the YPA. Thus, for one side (Serbia), the role of YPA was understandable and just, while for others (Croatia and Bosnia) it was confusing, fearsome and unjust. Taking into account these events, one can understand the different relation of today's Yugoslav states, that shifts from defining the YPA as pro-Serbian and as a killer, to magnifying the generals that have led it.

\section{What was YPA like during Yugoslavia?}

The Yugoslav People's Army was an integrative part of society, ideologically related to the Union of Communists of Yugoslavia, tightly connected to the President of the state, Marshall Josip Broz Tito and based upon the doctrine of "brotherhood and unity". Its basic task was protection of statehood, the unity and the sovereignty of SFRY from the outside enemy. The relation of the army with the party was established immediately after the liberation, when the national organizations were also established - firstly in Slovenia, Croatia and Macedonia, and then in Serbia and in the other republics. Later on, the theoretical and ideological education in the frames of the army included officers and soldiers alike, through different courses and though attending the organized party schools. Communism as the only option was propagated through army printed editions, newspapers, magazines, and especially though continuous moral and political couching of the cadres. The symbolical aspect was also present, so through the whole period of YPA's existence the red five-beamed star was the basic symbol present on the caps and on the uniform, combined with the symbol of the military service branch (army, air force and marine corps), but also in terms of a suitable

11 Titostalgia, Titoism, Yugonostalgia / Yugonostalgics...

12 Velikonja M. 2010. Politička mitologija nepostojećeg - narativni sadržaji jugonostalgije u postjugoslovenskim zemljama [Political Mythology of the Non-existent - narrative contents of Yugo-nostalgia in Post-Yugoslav countries], Mitovi epohe socijalizma, Novi Sad, 131. 
ideological, party and social political instruction, which continuously stressed upon the importance of unity of everyone in Yugoslavia, promoting the motto of brotherhood and unity. Religion was forbidden and sanctioned for a long time. Accordingly, the YPA did not have direct contacts with the existing religious communities, but it was connected with them through other state institutions, such as the Federal Executive Board or though the commissions for relations with the religious communities at federal or at republic level. However, it is understandable that religious functionaries, believers or religious people from all religions in the state have served the army. They were under special surveillance, in case they propagate any of the faiths and try to influence other soldiers on religious grounds. In each military structure or unit there were soldiers of different national and religious background, there were also atheists, so any type of public practicing of a religious ritual could be considered an offence concerning the feelings of other soldiers, belonging to another religion. In this sense the officers and other citizens working in the army were not exempted, even members of their families. Living in collective communal buildings and settlements, they could easily follow and control each other. My first information on celebrating Easter came from my class-mates, during my first year in primary school. ${ }^{13}$ My father, as a professional soldier who at that time believed in the common Yugoslav model of the state and the system, has strictly followed these rules. Neither me, nor my brother, were baptized in a church although by tradition we belonged to the Christian, Macedonian Orthodox Church. We did this much later, after our $30^{\text {th }}$ birthday, following our own desire to get baptized. The promoted politics of religious and national equality that was the basic postulate of the Communist Party of Yugoslavia, should have enabled "equal national representation in the governing bodies, the justice system, the governance, the security institutions, it should have provided an uninhibited development of national cultures, creation of schools where pupils could learn in their mother tongues, an utilization of these languages in every-day communication, right to national cultural institutions (theatres, homes of culture) and the press."14 This was provided by the theoretical regulation, constantly emphasized through the educational system in the multinational structures, organizations and bodies at the federal level - the rules and the regulation were built upon this base. The common person, who was not involved in any official state, party or army body, nor the numerous organizations or associations that were formed by the state, shared this opinion. The role of the CPY, i.e. its continuous presence in the public media - radio and $\mathrm{TV}$, created conditions that even then were not very visible and recognizable for the common Yugoslav from any ethnic group, that led to something that from today's perspective could be defined as mythology. Counting even 22 myths, one

13 Мирчевска М. 2006. 'Между вярата, традицията и забавлението (антроположки поглед)', in „Заврьщане“ на религиозността, Academica Balkanica 3: 59. София: БАН.

14 KPJ u socijalističkom sistemu i unutrašnjopolitički odnosi [CPY in the Socialistic System and Inter-political Relations], Socijalistička Jugoslavija, 4 http://www.znaci. net/00001/95 2.pdf 
of the researchers calls this "a Communist mythocreative praxis" ${ }^{15}$ Although the named mythologies are related by the author to the socialistic society and the $\mathrm{CPY}$, that helped fueling a "powerful and convincing Communist propaganda", she also elaborates that those are not uncommon and were not invented by the Communist, but that they have been "cunningly upgraded the already existing and recognizable layer of mystical conscience of every person", and that this is the source of the "acceptability of the new-old myths that now bear a socialistic mark" ${ }^{16}$ Here one could question the differences of the ex-Yugoslav people and ethnic groups: the different historical context, the time and the different geographical and cultural space, the alternative starting positions and previous social orders, thus the different possibilities for development, progress, accepting or rejecting ideologies. With no intention to judge or to support any of them, if one analyzes only the way CPY/UCY functioned from today's perspective, without taking into account the previously named elements, then one obtains an image of something that takes place outside historical time at the level of a wider Balkan and European space during the same period. An important point of comparison would be the way socialism/communism was practiced in other socialist states, especially in the USSR.

The connection of the President of the state Josip Broz Tito with the YPA was understandable, since he was at the same time the supreme commander of the army. He obtained this role based upon his successful participation in the People's Liberation war, during the Second World War, something that has not been a topic of dispute neither in the past, nor today. The population of the ex-Yugoslav republics has never opposed this fact. Surely there are different opinions, but those are often related to articles that deal with researching the ways, methods, the role and the level of significance of the President for the final victory over fascism in the period $1941-1945 \cdot{ }^{17}$

The phrase "brotherhood and unity" was the most exploited term in socialist every-day life. ${ }^{18}$ Even at the first school classes teachers spoke about unity and equality of all people and ethnic groups in SFRY. This was especially emphasized in the frames of the YPA. Yugoslav identity in the army was not promoted or stimulated. On the contrary, everyone knew where they came from and what nationality they were, without any pressure being made in this sense. It was somehow self-evident, but never accented. There was no visible strategy to make the soldiers accept the Yugoslav identity. Although certain papers point towards the opportunity that though the promoted model of behavior, the

15 Despotović Lj. 2010. Politički mitovi socijalizma od komunizma do boljševizma [The Political Motives of Socialism from Communism to Bolshevism], Mitovi epohe socijalizma, Novi Sad, 8.

16 Idem, p. 11.

17 In this paper I will not speak about the role of Josip Broz Tito. This is a topic of a separate article in progress.

18 "Keep brotherhood and unity as the iris of your eye" was the famous motto of Josip Broz Tito. 
message was empirically registered as one of promoting the Yugoslav affiliation. ${ }^{19}$ Even the Marshal himself has stated that "to love one's own federal unity means to love Yugoslavia as a whole" and that the people should be "armed with such awareness so that the Croat would be worried about what happens on the border of Macedonia, and the Serb about what is happening in Istria." ${ }^{20}$

\section{Narrative ethnology/anthropology}

A topic for deliberation of each ethnologist, when they work upon a certain topic, is the narration, the collection of first-hand field material, that they place later on in the frames of a certain theory or explain through using a concrete methodology. In any case, my narration refers to a part of civil life of the recruits before they become soldiers of the YPA, as a part of the rituals that include traditional practices that were party present after the formation of the Army of the Republic of Macedonia.

\section{Banquet/seeing off}

The departure of the soldier was celebrated with a party, known under the name "isprakjaj" or "banket". The "banket" almost always meant organizing a seeing-off for a member of the family before he joined the army. This term was not used for anything else. Thus, when someone would invite you to a banquet you would know that you are invited to see off someone leaving for the YPA. The official name for the young man who prepared to become a soldier is a recruit, but this term was almost never used in every-day speech. The young man was named 'a soldier' even before becoming one. The invited guests were members of the close family, relatives, friends, work colleagues, neighbors. Often it was organized the night before departure if the soldiers traveled in the morning, or one day before the trip if he was to travel the next night. There was a certain difference between the urban and the rural environments. The well-off families paid "live music", so that the celebration lasted through the night. In some settlements around Skopje ${ }^{21}$, the celebration lasted for few nights in a row with the main celebration taking place at the last day before departure. Usually the guests would bring cakes, something sweet, and gifts for the soldier, mostly money. In the cities the host verbally invited the guests, including friends of the soldier. My brother (1963) and my husband (1960) both organized "isprakjaj" and made a banquet. In our house, at the banquet (1985) mostly relatives were invited (brothers and

19 Dimitrijević B.B. 2001. 'Armija i jugoslovenski identitet 1945-1992. Godine' [The Army and the Yugoslav Identity 1945-1992], Vojno delo, 53(2): 141-154. Beograd.

20 KPJ u socijalističkom sistemu i unutrašnjopolitički odnosi, Socijalistička Jugoslavija, 5 http://www.znaci.net/00001/95 2.pdf

21 The village of Dolno Kolichani, inhabited by Macedonians with Muslim religion, settled here from the region of Reka, that according to the census (2002) declare themselves Turks. 
sisters of my parents and their families), close friends, neighbors and my brother's friends. This meant that there were not only visitors from Skopje, but also from the cities where our relatives lived (Struga), while my mother's sister came all the way from Belgrade..$^{22}$ There were around 30 people. There was no live music, partly because we lived in a so called army building, where all inhabitants were officers of the YPA and no one had live music when they organized banquets. My brother was also against it. However, there was music playing from a cassette player, everyone sang and danced until late in the night. Food abundance was a must, while a roasted pig was brought all the way from Belgrade. The banquet of my husband, in 1984, had even more guests, since his parents were from Skopje and all relatives lived here, around 60 of them. Besides, my husband used to be a dancer in a folklore ensemble, so live music was indispensable. He also lived in a barrack ${ }^{23}$, and the party was easily organized, since people could dance in the garden and on the street. There was also plenty of food, but there was no roasted pig, since the Macedonian traditional food does not include it, even with the well-off population, while the Serbian population prepares roasted pigs even for smaller family celebrations.

Surely, there were certain exceptions from the usual practice, stemming from few elements: financial situation; having a number of male children for whom a banquet is needed - if one gets a celebration, everyone else should receive the same; members of certain religious communities; due to less positive attitude towards the YPA; higher educational level of a part of the soldiers (or their parents) etc. ${ }^{24}$ Still, none of these reasons dominated in a certain period. Even people who were not so well-off at least offered dinner only for the members of the family and maybe would invite a closer relative. In most of the cases even the poorer tried to offer a banquet for their son, especially if he was the only son in the family. The family would save money and a part of them were spent on this occasion. In the period when I went at banquets (1980-1990) almost everyone that I knew organized a banquet prior to joining the army. In the army building where I lived, my husband's street and in the villages and the cities where my parents and the parents of my husband came, in the folklore ensemble, the school... almost everyone organized a celebration. This was even more emphasized in the rural regions. There the public manifestation of the financial status, as well as the

22 When my aunt's son from Belgrade went to the army, the same relatives were present at his banquet there.

23 After the earthquake in Skopje (June 1963), during 1964, a part of the city's inhabitants that were left without a home received prefabricated houses. The family of my husband has received, as a gift from Finland, a montage house of 64 square meters, that had excellent isolation - those were the best montage houses that the city has received. Many of them, if they are well kept, are in great shape even today. They are called barracks, or "Finish barrack".

24 More than half of my friends that are highly educated, or the ones whose parents have graduate from college, have organized such celebration. However, some of them have graduated after serving in the army, since my high-school generation (1980) was the first one when man would go to the army immediately after finishing high school, and after enrolling at the University, even before starting with lectures. The October class contained mostly recruits that have enrolled at the University, especially in the first years after the law was introduced. 
relation towards the YPA, was very important. The family wanted to show that it respects the army and their son, but also to show its status in the community. This was not a rule, but surely was a dominant model of behavior. Even in the cities, there was an accepted ritual praxis, similar for the whole Macedonian cultural context, but also with concrete specificities. Most of them were performed prior to departure, prior to exiting the house, at the family door-step or the garden as the family ritual space, but also before entering the bus or the train. A mutual characteristic of the ritual practice, registered in a number of ethnographic regions in the Republic of Macedonia, is the presence, the utilization and the role of the water and the ax, that is the metal that has a protective function. In the urban settlements the water is poured after the soldier when he leaves, as a part of the female ritual practice. This is done by the mother or the sister, but somewhere, especially in the villages, there is an older form of a ritual where the soldier kicks the water vessel (in the past made of ceramics, later on a glass vessel or a drinking glass, a bucket) so that the water spills, symbolizing an easy flow of the time served in the army. In Strushki Drimkol, the Macedonians with Muslim religion, i.e. the women, after they toss the water, say a prayer whispering. In Dolno Kolichani, the soldier has a precise role in this ritual, after he jumps over the ax and the water vessel, and with his back towards it kicks it with the sole of his foot. A similar ritual with different belief exists in the Ohrid region, when in front of the door-step a metal vessel full of water is being left, the soldier exits though the door step and with his leg, without looking, kicks the vessel ${ }^{25}$, that should be spilled after the third try, in the direction towards the house. The symbolic of this ritual is to provide an easy return of the soldier home after he serves the obligatory army time, the same way the water finds its way to the house. In the region of Kochani during the same ritual, the vessel should be broken kicking with the right foot, while in the Berovo region the recruit at the exit of the house breaks a glass of water. During this ritual the soldier should not turn facing home. In many villages around Macedonia there is a certain local place where soldiers gather before departure. ${ }^{26}$ Since most of the recruits from Macedonia went to other Republics, one had to first arrive to Skopje. This was a challenge especially for those villages and cities that did not have a rail-road connection. Buses, and later on cars were used to come to Skopje. From there everyone left by train to the designated place. The Skopje railway station in the period when recruits left was full of them. Such public places exist in Negotino, the city square, in Dolna Reka in Rostushe where the soldier meat at a certain place in the village, and in the village of Injevo near Radovish, where such gathering place is located at the end of the village and is called "waiting room". Such gathering spots existed in

25 Here there is no ax present, but the symbol of the metal as a hard substance is personified through the vessel which is made of metal. The symbolic of the door-step as a border between "one's own" and "someone else's" territory is present in these rituals too.

26 During the existence of Yugoslavia, the invitation to the army was called "poziv" since this was the word written on it. The official language in the YPA was Serbo-Croatian using Latin script, and all communication, verbal and written, was done in this language. Thus for everyone the invitation was "poziv". 
all bigger villages, or there was a mutual one for a number of villages. This social gatherings gave the recruits the needed self-confidence, not to be afraid of going to the army, since for many this was their first exit from the village or the city in a totally unknown city or place that they have never heard about before. Suspense was present especially with the younger population. They have spent a part of the trip together, talked about the places where they will serve etc. The soldier was carried to the gathering spot, and in Skopje often to the railway station, by his friends, while singing. During this period the songs were Yugoslav, and people would not make much difference between Serbian, Croatian or Bosnian songs - for many people these belonged to the same group, although they were aware that they stem from the tradition of different cultures. The most popular were "Oj mashino pusti dima jache da ne chujem kako draga place" (Oh engine, make more noise, so that I cannot hear my darling crying) and "Ne plachi, ne plachi, stisni srce majko zatraj se” (Don’t cry, don't cry, be strong mother).

Surely after the dissolution of Yugoslavia and the formation of independent Republic of Macedonia, many things changed. Banquets could be rarely seen later on. One could note the tendency of reduction of the manifest forms of the ritual praxis. Often this was only a small family meeting, or a lunch. Without any doubt this was a result of a number of changes that took place in every-day life and culture in general, so other types of public celebrations became more important. What also changed was the role, the status, the needs and the legal regulation of our Macedonian army, that is not the same as the ones of the YPA.

\section{References}

Мирчевска, Миряна. 2006. „Между вярата, традицията и забавлението (антроположки поглед)“, „Завръщане“ на релийиозносийа. Academica Balkanica 3: 50-62. София: БАН.

Мирчевска, Мирјана П. 2014. „Конструирање на сегашноста преку преиспитување на минатото: помеѓу јавниот дискурс и личната перцепција“. In: За ейнолойијайа... Безброј йраїови сме ирреминале... За Анейа Свешиева. Љупчо Ристески и Ана Ашталковска Гајтаноска (eds.)., 155-170. Скопје: Институт за етнологија и антропологија, ПМФ.

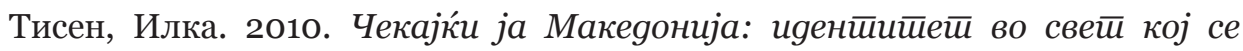
менува. Скопје: Табахон.

Despotović, Ljubiša. 2010. „Politički mitovi socijalizma od komunizma do boljševizma“. Mitovi epohe socijalizma, 5-29. Novi Sad: Centar za isto- 
riju, demokratiju i pomirenje - Sremska Kamenica: Fakultet za evropske pravno-političke studije.

Dimitrijević, Bojan B. 2001. „Armija i jugoslovenski identitet 1945-1992.“ Vojno delo 53(2): 141-154. Beograd.

Kuljić, Todor. 2003. „Tito u novom srpskom poretku sećanja“. Sociologija XLV(2): 97-116. Beograd.

Rihtman-Auguštin, Dunja. 1992. „Etnologija socijalizma i poslije“. Etnološka tribina 15, Zagreb.

Velikonja, Mitja. 2010. „Politička mitologija nepostojećeg - narativni sadržaji jugonostalgije u postjugoslovenskim zemljama“. In: Mitovi epohe socijalizma, 131-148. Novi Sad: Centar za istoriju, demokratiju i pomirenje Sremska Kamenica: Fakultet za evropske pravno-političke studije.

KPJ u socijalističkom sistemu i unutrašnjopolitički odnosi, Socijalistička Jugoslavija, 4. http://www.znaci.net/00001/95_2.pdf

KPJ u socijalističkom sistemu i unutrašnjopolitički odnosi, Socijalistička Jugoslavija, 5. http://www.znaci.net/00001/95 2.pdf 

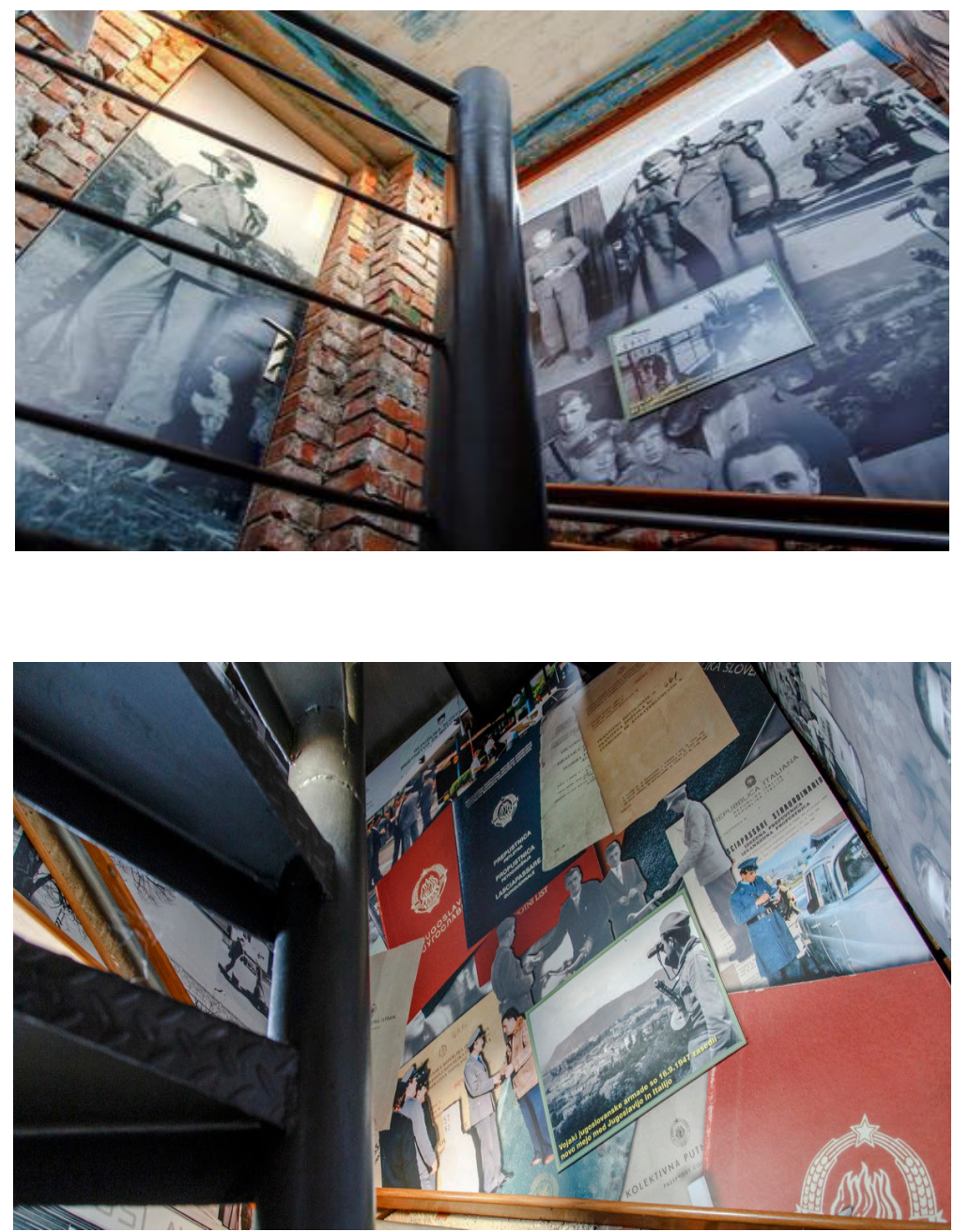

A military watchtower stands in Vrtojba, just off the former ItalianYugoslav state border. It was erected in 1948 by the Yugoslav army and used for border control until 1991. In 2006, the Gorizia Museum transformed it into a small memorial museum, the smallest in Slovenia. It shows an exhibition about life along the new state border, which in 1947 divided the then unified cultural, social, economic and political territory of Gorizia into two parts. The magnificent view from the tower reveals to us the surroundings which, especially during the Cold War, were strictly controlled. At the initiative of the Museum of Gorizia, the municipality of Shempeter-Vrtojba declared the military guard tower a cultural monument of local importance and protected it from collapse ${ }^{27}$.

27 From the official site of the city of Nova Gorica, Republic of Slovenia 
EthnoAnthropoZoom

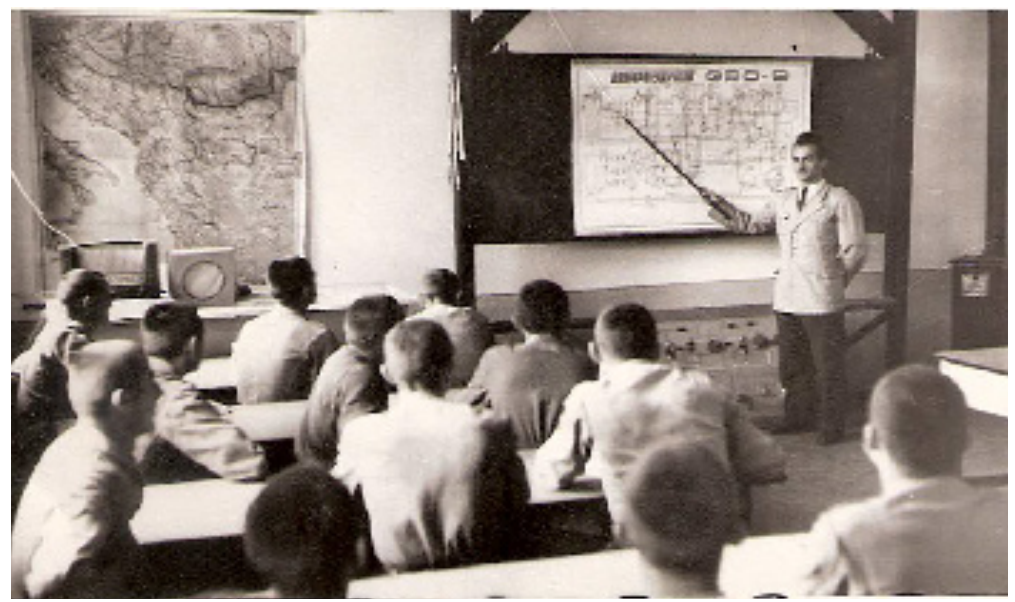

$\int_{0} \cos ^{5 n^{*}}$

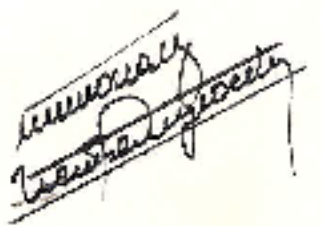


EthnoAnthropoZoom
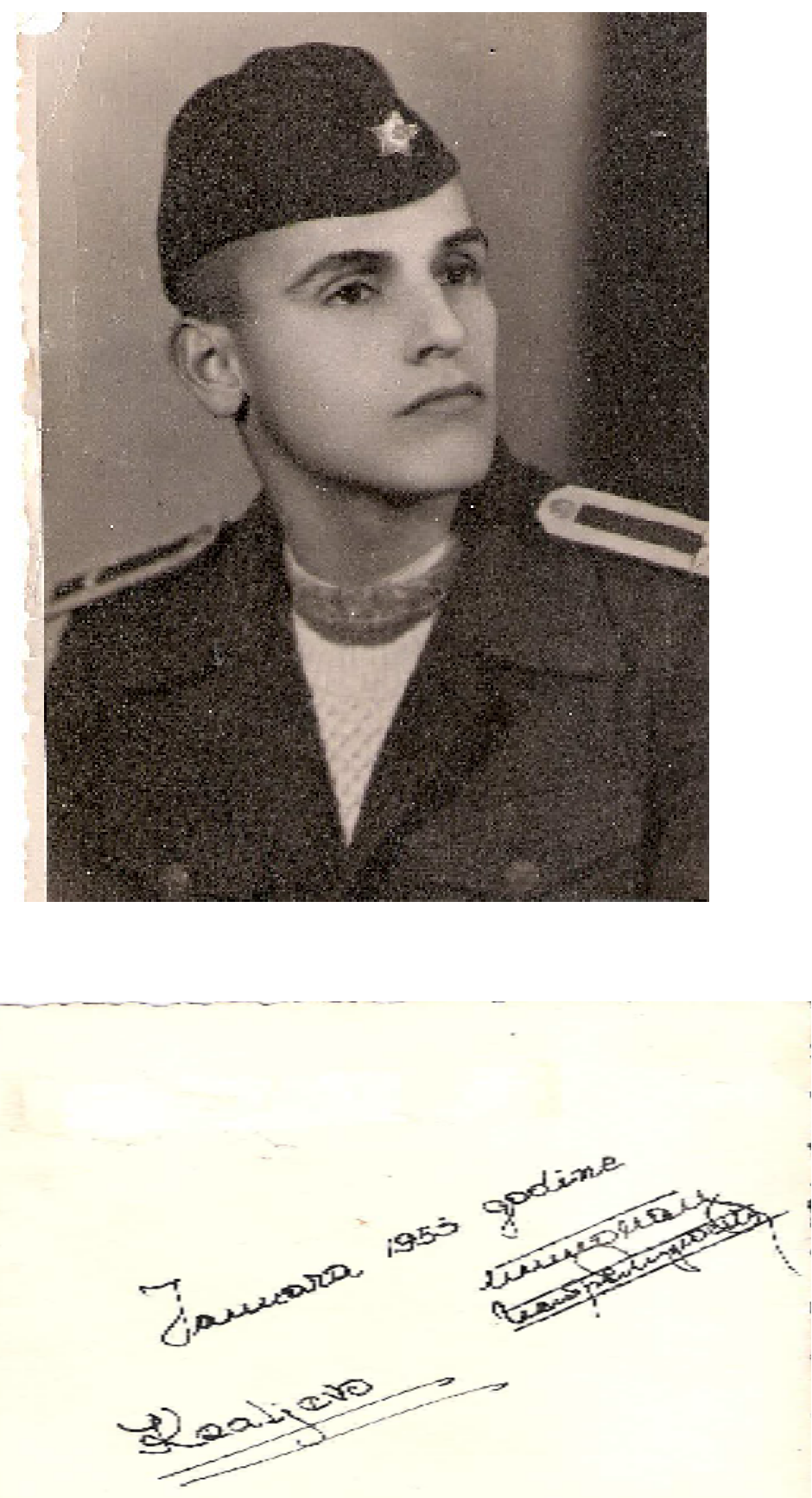
EthnoAnthropoZoom 
EthnoAnthropoZoom 